\title{
Plasticity of Body-Centred Cubic Metals at High Strain Rate*
}

\author{
By Isao Gokyu** and Junji Kihara***
}

\section{Synopsis}

Stress - strain curves of metals mentioned in the title were obtained at high strain rate and various temperatures above room temperature by "counterblow" forging tester. The strain rate can be varied from $3 \times 10^{2} / \mathrm{sec}$ to $10^{3} / \mathrm{sec}$ by changing the angle of lifting hammers. The main experimental results are as follows:

(1) Many investigators have reported that the strain-rate dependence of flow stress of metals and alloys increases with temperature. But in the authors' experiment, such a general conclusion can not be adopted to that in the cases of iron, steel and tantalum at strain rate of $10^{2} / \mathrm{sec}$.

(2) At lower temperature, large strain-rate dependence of flow stress is found in the cases of $\mathrm{Ta}, \mathrm{C}$ steel and $2 \% \mathrm{Al}$ iron. The temperature dependence corresponds almost always to the strain-rate dependence. But that of $0.02 \% \mathrm{C}$ steel, $0.05 \% \mathrm{C}$ steel containing $\mathrm{Ni}, 2 \% \mathrm{Al}$ iron and $\mathrm{Ta}$ is small at the lowest part (below $150^{\circ} \mathrm{C}$ for the iron and steel, and $200^{\circ} \mathrm{C}$ for $\mathrm{Ta}$ of the temperature range.

(3) In the case of tantalum, a peak of stress-temperature curves is found where the strain-rate dependence is large. It is the different point of flow-stress behaviour from that in the case of iron and steel.

(4) The flow-stress behaviour at lower temperature range mentioned above can be interpreted by the double-kink formation mechanism on moving dislocations.

(5) In the case of $1 \% \mathrm{Si}$ iron, the flow-stress behaviour below $300^{\circ} \mathrm{C}$ is of the same nature as that of steel, whereas that above $300^{\circ} \mathrm{C}$ (small temperature and strain-rate dependence of flow stress) must be due to the local order-hardening effect.

(6) A peak found at $650^{\circ} \mathrm{C}$ on stress-temperature curves in the case of steel must be due to the interaction between interstitials and dislocations. But the dragging mechanisms fail to explain higher work-hardening rate and higher density of dislocations. Then the other mechanism exists, but it is not yet clear.

(7) At higher strain rate no peak is found on stress-temperature curves in the $\alpha-\gamma$ coexisting temperature range, whereas at lower strain rate a peak exists. The reason is that strain-rate dependence of flow stress is higher in $\alpha$-phase temperature than that in $\gamma$-phase temperature.

\section{Introduction}

In 1940, M. Manjoine and A. Nadai noticed in their first paper ${ }^{1)}$ about high speed tension tests at elevated temperature, "The continuous hot and cold mills built during the last 10 to 15 years in this country stand out as one of the most remarkable developments in the mass production of steel...... Very little is known about the forces required for the pure plastic forming of steel and of other ductile metals at the high straining velocity used for rolling of sheets......."

Since 1940, many investigators have reported the data about the stress - strain relations at elevated temperatures and high strain rates of common metals as well as steel. Many of their works have been done from the point of view of mechanical engineers. There is much reliable knowledge for the rolling-mill practice about such stress-strain-strain-rate relation as an experimental equation, i.e.

$$
K_{f}=K_{0} \varepsilon^{m} \dot{\varepsilon}^{n} e^{A / k T}
$$

where $K_{f}$ is flow stress, $\varepsilon$ is strain, $\dot{\varepsilon}$ is strain rate, $k$ is Boltzmann's constant, $T$ is absolute temperature and $m, n$ and $A$ are constants. Below $10^{2} / \mathrm{sec}$, of strain rate for the flow stress of metals and alloys, it is said that the strain-rate dependence exponent $n$ is small at low temperatures, whereas larger at higher temperatures, as shown in Fig. 1.

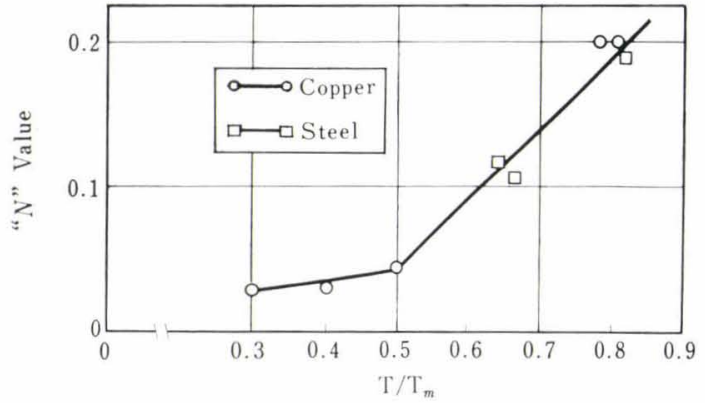

T: Testing temperature $\left({ }^{\circ} \mathrm{K}\right.$

$\mathrm{T}_{m}$ : Melting temperature $\left({ }^{\circ} \mathrm{K}\right)$

Fig. 1. The strain-rate dependence exponent " $n$ " and testing temperature ${ }^{2}$

Now in Japan, many investigators ${ }^{2-4)}$ ) have studied on the stress-strain-strain-rate relation and ductilities of various sorts of steels at various temperatures, and the data have been utilized in autocontrolling of hot and cold stripmill practices.

The authors can measure the stress - strain curves of metals at the strain rate of magnitude of $10^{2} / \mathrm{sec}$ at various temperatures above room temperature by the counter-blow-type forging tester. The out-lined feature of tester and the block diagram of the measuring system are shown in Fig. 2.

In this paper, the problems as follows are studied.

The Strain-Rate Dependence of Iron and Steel from Room Temperature to $1000^{\circ} \mathrm{C}$ at Strain Rate of $10^{2} / \mathrm{Sec}$.

As shown in Fig. 1, at low temperature the strainrate dependence indicated by $n$ in the equation (1) is small, but at higher temperature large. However, this is not true for the authors' experiments especially in the case of steel.

The Effect of Solute Atoms of Flow Stress

What effect have solute atoms but for carbon and

* This article is requested by Editorial Committee of The Iron and Steel Institute of Japan. Japanese text was received on November 11, 1965 and printed in Tetsu-to-Hagané (Journal, Iron \& Steel Institute, Japan), 52 (1966), 5, 837-853.

** Prof., Dr. Eng., The University of Tokyo.

*** Dr. Eng., The University of Tokyo. 


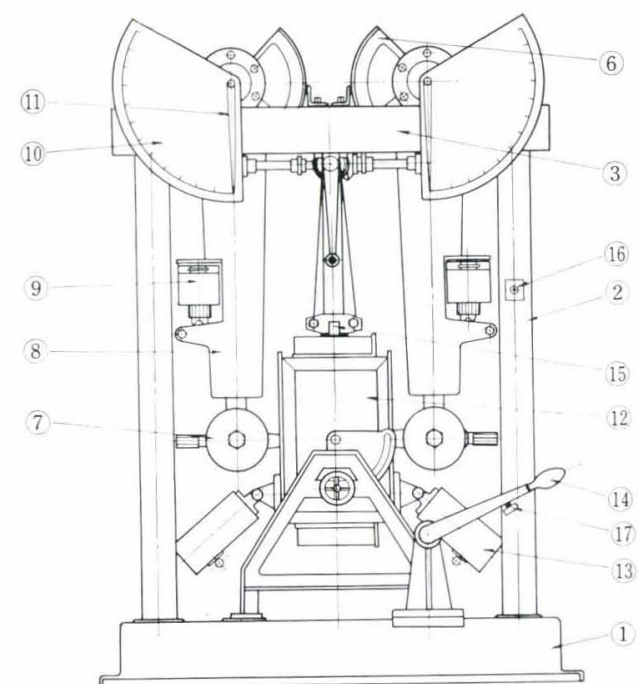

(a) The outlined feature of the forging tester

1. Bed

2. Support

3. Upper beam

4. Hundle for lifting hammers

6. Gears for lifting hammers

7. Hammder

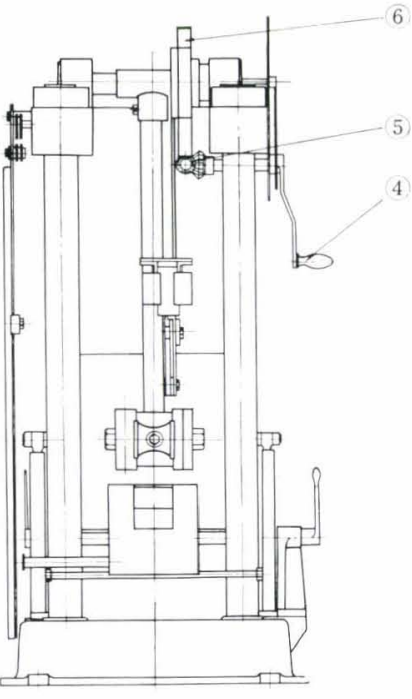

13. Flap of the furnace

14. Hundle for flaps

15. Accesary for opening and closing flaps

16,17. Switches for releasing hummer catchers

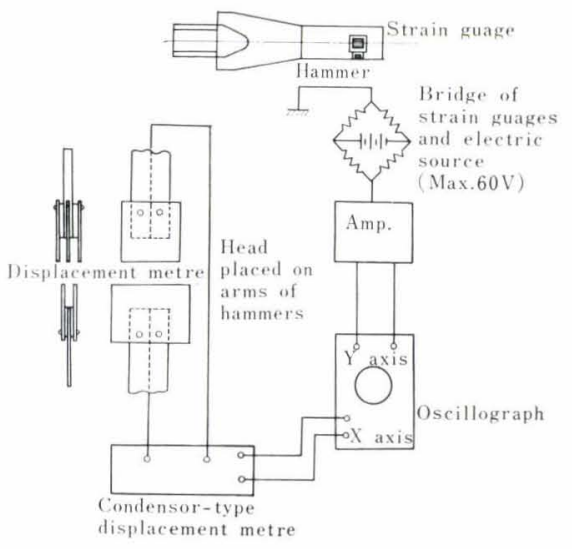

(b) Mechanism of the measurement of back strain diagram

Fig. 2. The counter-blowing forging tests designed by the present authors

nitrogen on the strain-rate and temperature dependence of the flow stress of steel? It is discovered that silicon has the remarkable effect on the strain-rate and temperature dependence to be much smaller at the temperature range between $300^{\circ}$ and $650^{\circ} \mathrm{C}$.

\section{Experimental Procedure and Materials}

As mentioned above, the stress - strain curves at various deforming conditions, i.e. from room temperature to $1000^{\circ} \mathrm{C}$ at strain rate of $10^{2} / \mathrm{sec}$, were measured by the counter-blowing type forging tester shown in Fig. 2. The testing samples are cylindrical and of the size of 9-10 $\mathrm{mm}$ in diameter and 9-10 $\mathrm{mm}$ in length, respectively. The testing conditions are shown in Table 1 and the chemical compositions are shown in Table 2.

In this paper, the main part of the experiments is on the temperature and strain-rate dependence of the flow stress of mild steel. In addition, for the sake of comparing the flow mechanism of iron and steel

Table 1. Conditions of experiments

\begin{tabular}{|c|c|c|c|}
\hline Specimen & Testing temp. $\left({ }^{\circ} \mathrm{C}\right)$ & $\begin{array}{c}\text { Strain rate } \\
\left(\mathrm{sec}^{-1}\right)\end{array}$ & Lubrication \\
\hline $0.09 \% \mathrm{C}$ steel & $\begin{array}{c}\text { Room temp. } \\
200-860 \\
900\end{array}$ & $\begin{array}{l}400-1080 \\
300-1080 \\
300-1080\end{array}$ & $\begin{array}{c}\mathrm{MoS}_{2}+\text { grease } \\
\mathrm{MoS}_{2}+\text { grease } \\
\text { glass }\end{array}$ \\
\hline $0.02 \% \mathrm{C}$ steel & Room temp. to 850 & $300-1000$ & $\mathrm{MoS}_{2}+$ grease \\
\hline $0.04 \% \mathrm{C}$ steel & $700-1000$ & $300-1000$ & $\mathrm{MoS}_{2}+$ grease \\
\hline $0.04 \% \mathrm{C}$ steel-I & $700-1000$ & $300-1000$ & $\mathrm{MoS}_{2}+$ grease \\
\hline $\begin{array}{l}0.05 \% \mathrm{C} \text { steel-II } \\
\text { and } 0.05 \% \mathrm{C} \text { steel } \\
\text { containing } \mathrm{Ni} \\
\text { and } \mathrm{Cr}\end{array}$ & Room temp. to 600 & $300-1000$ & $\mathrm{MoS}_{2}+$ grease \\
\hline $2 \%$ Al-iron & Room temp. to 1000 & $300-1000$ & $\mathrm{MoS}_{2}+$ grease \\
\hline $1 \%$ Si-iron & Room temp. to 1000 & $300-1000$ & $\mathrm{MoS}_{2}+$ grease \\
\hline $\mathrm{Ta}$ & Room temp. to 1200 & $300-1000$ & $\mathrm{MoS}_{2}+$ grease \\
\hline
\end{tabular}

at strain rate of $10^{2} / \mathrm{sec}$ with that of $\mathrm{Ta}$ which has also body-centred cubic structure, the temperature and strain-rate dependences of the flow stress of Ta were measured, too. The chemical composition is also shown in Table 2.

The specimens were prepared in such ways as shown below.

\section{$0.09 \%$ C Steel}

The cylindrical specimens of $10 \mathrm{~mm}$ in length and $10 \mathrm{~mm}$ in diameter were made of the $10 \mathrm{~mm}$ diameter rimmed steel wire rod. They were annealed for $1 / 2$ hr. at $900^{\circ} \mathrm{C}$ in cast iron powder.

\section{$0.02 \%$ C Steel}

This is used as one of the soft electro-magnetic materials. The specimens of $10 \mathrm{~mm}$ in length were made of wire rod of $9.5 \mathrm{~mm}$ in diameter. They were annealed for $1 / 4 \mathrm{hr}$, at $950^{\circ} \mathrm{C}$ in vacuo.

\section{$\mathbf{0 . 0 4} \%$ C Steel}

The specimens of $10 \mathrm{~mm}$ in length were made of rimmed steel wire rod of $10 \mathrm{~mm}$ in diameter, and were annealed for $1 \mathrm{hr}$. at $950^{\circ} \mathrm{C}$ in vacuo.

\section{$\mathbf{0 . 0 5} \%$ C Steel-I}

The cast ingot was hot-forged to $50 \mathrm{~mm}$ in diameter, reduced to $12 \mathrm{~mm}$ in diameter by hot rolling and cold drawing, and annealed for 2 hrs. at $900^{\circ} \mathrm{C}$ in the air. The specimens of $10 \mathrm{~mm}$ in length and $10 \mathrm{~mm}$ in diameter were made of it.

\section{$\mathbf{0 . 0 5} \% \mathrm{C}$ Steel-II and the Eight Sorts of $\mathbf{0 . 0 5} \% \mathrm{C}$ Steel Con- taining $\mathrm{Ni}$ and $\mathrm{Cr}$}

Each material was made from electrolytic iron, metallic Ni and Cr. Carbon content was attained by mixing the proper weight of pig iron. $1200 \mathrm{~g}$ of the iron and $\mathrm{Ni}$ (in the case of steel containing $\mathrm{Ni}$ ) was charged in the electronic high frequency melting furnace $(15 \mathrm{~kW}, 30 \mathrm{kc})$, melted and held for $5 \mathrm{hrs}$. in $\mathrm{H}_{2}$ gas for reducing. Then, the gas was pomped out, Ar gas was charged in turn there and $0.015 \mathrm{wt} \%$ of 
Table 2. Chemical compositions of specimens (\%)

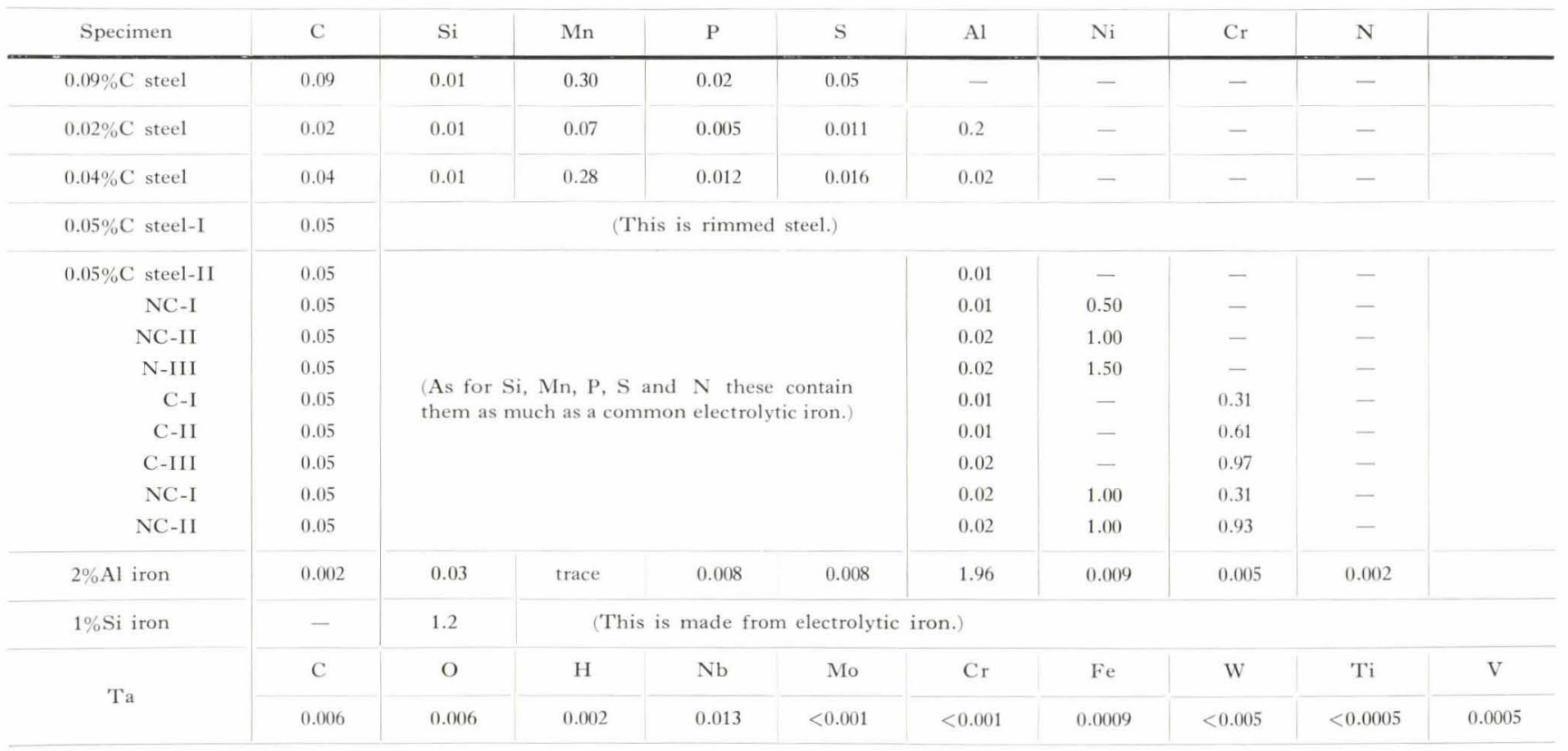

$\mathrm{Al}$ was added in the melt. Carbon was alloyed in the form of pig iron together with metallic Cr (only in the case of steel containing $\mathrm{Cr}$ ), held for 3 min., subsequently solidified in the crucible used for melting.

The cast ingot of $50 \mathrm{~mm}$ in diameter and $100 \mathrm{~mm}$ in length was hot-forged to $12 \mathrm{~mm}$ in diameter and cold drawn to $9 \mathrm{~mm}$ in diameter. The specimens of $10 \mathrm{~mm}$ in length were made of it, and annealed in vacuo for $1 \mathrm{hr}$. at $900^{\circ} \mathrm{C}$.

\section{$2 \%$ Al Iron}

The zone refined electrolytic iron was melted in vacuo, and $\mathrm{Al}$ was alloyed to $2 \mathrm{wt} \%$, so that this alloy is in $\alpha$-phase at every temperature. It was cooled and solidified in the crucible, and the cast ingot was of the size : $50 \mathrm{~mm}$ in diameter and $250 \mathrm{~mm}$ in length. This ingot was hot-forged at $700^{\circ} \mathrm{C}$ in $\mathrm{Ar}$ gas and reduced in diameter to $12 \mathrm{~mm}$. Then, by cold drawing the rod of $9 \mathrm{~mm}$ in diameter was obtained. The specimens of $10 \mathrm{~mm}$ in length were made of it and annealed in vacuo for $1 \mathrm{hr}$. at $900^{\circ} \mathrm{C}$.

$\mathbf{1} \%$ Si Iron

Electrolytic iron and metallic Si were melted and alloyed in the air. Si content is about $1 \%$. This alloy was casted in a metallic mould. It was of the size, $50 \mathrm{~mm}$ in diameter and $100 \mathrm{~mm}$ in length. This ingot was hot-forged at $1000^{\circ} \mathrm{C}$, reduced in diameter to $12 \mathrm{~mm}$ and cold drawn to $9 \mathrm{~mm}$ in diameter. The specimens of $10 \mathrm{~mm}$ in length were made of it and annealed for $1 \mathrm{hr}$. at $900^{\circ} \mathrm{C}$.

Ta

The specimens were made of DF-381 produced Kobe Steel, Ltd. The size is of $9 \mathrm{~mm}$ in diameter and length. They were annealed for $1 \mathrm{hr}$. at $1300^{\circ} \mathrm{C}$.

\section{Experimental Results}

\section{$0.09 \%$ C Steel}

The stress-strain curves from room temperature to $900^{\circ} \mathrm{C}$ are shown in Fig. 3. From room temperature to $400^{\circ} \mathrm{C}$, the mode of strain-hardening is mild and the strain-rate dependence of flow stress is large. The strain-rate dependence exponent is of the magnitude of $0.15-0.20$.

At $600^{\circ} \mathrm{C}$, the strain-rate dependence of flow stress is still large, and strain hardening becomes larger

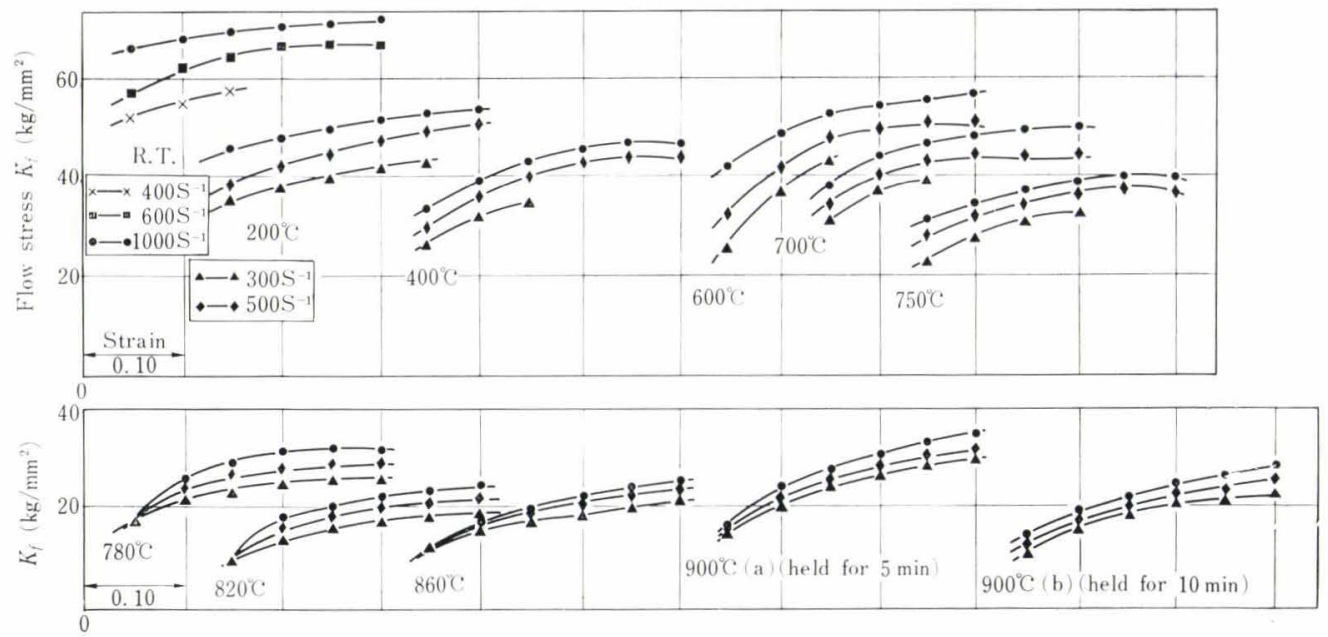

Fig. 3.

Stress-strain curves of $0.09 \% \mathrm{C}$ steel at various temperatures above room temperature to $900^{\circ} \mathrm{C}$ 
than one at the lower temperatures. At strain of 0.10 the flow stress at $600^{\circ} \mathrm{C}$ is of the same magnitude as that at room temperature.

From $700^{\circ}$ to $820^{\circ} \mathrm{C}$, the strain-rate dependence of flow stress becomes smaller and the dependence exponent decreases to about 0.12 and strain-hardening is mild again. However, the temperature dependence of flow stress is much larger. At $860^{\circ} \mathrm{C}$ the structure of $0.09 \% \mathrm{C}$ steel is composed of $20 \% \alpha$-phase and $80 \%$ $\gamma$-phase. The strain-rate dependence of flow stress is much smaller than that at the other temperature and dependence exponent decreases to 0.05 .

The stress - strain curves at $900^{\circ} \mathrm{C}$ in the two cases are shown in Fig. 3. The case (a) is that of the specimens held for $5 \mathrm{~min}$. and the case (b) is that of the specimens held for $10 \mathrm{~min}$. The flow stress of specimens held longer is lower than that of ones held shorter, and the strain-rate dependence of that is also smaller. The flow stress at $860^{\circ} \mathrm{C}$ is less than that at $900^{\circ} \mathrm{C}$ in the both of two cases.

\section{$0.02 \% \mathrm{C}$ Steel}

In Fig. 4 the stress - strain curves of $0.02 \% \mathrm{C}$ steel at various temperatures are shown. Except for results from $500^{\circ}$ to $600^{\circ} \mathrm{C}$, at which the strain-rate dependence of flow stress is very small, the others are almost the same as in the case of $0.09 \% \mathrm{C}$ steel.

The temperature dependence of flow stress is known from Fig. 5 where stress-temperature curves at the strain of 0.10 are shown. It may be said that the curves have a knick point at $150^{\circ} \mathrm{C}$.

\section{$\mathbf{0 . 0 4} \% \mathrm{C}$ Steel and $\mathbf{0 . 0 5} \% \mathrm{C}$ Steel-I}

About $0.09 \% \mathrm{C}$ steel, it is found that the flow stress at $860^{\circ} \mathrm{C}$ is lower than that at $900^{\circ} \mathrm{C}$. Moreover, a peak of the flow stress-temperature curves at the

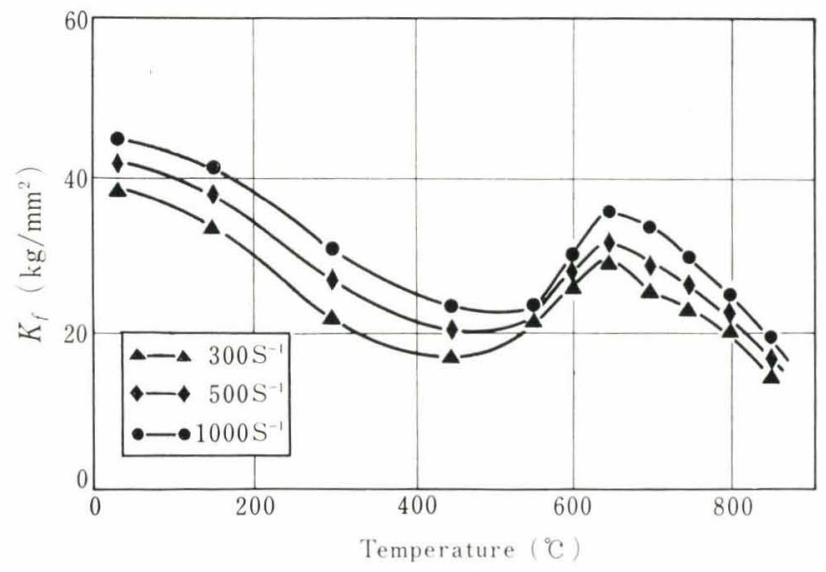

Fig. 5. $\mathrm{K}_{f}$-temperature curves at 0.10 strain of $0.02 \% \mathrm{C}$ steel temperature range where $\alpha$-phase transforms to $\gamma$-phase, has also been found by some investigators ${ }^{6), 7)}$. Then, the flow stress measurement about these steels was done between $700^{\circ}$ and $1000^{\circ} \mathrm{C}$. In Fig. 6 the flow stresstemperature curves are shown about those at the strain of 0.10. The curves shown in Fig. 6 (a) are of $0.04 \% \mathrm{C}$ steel and the others shown in (b) are of $0.05 \%$ C steel-I. In Fig. 6 (a), the experimental results at lower strain rate measured by Katoh* and
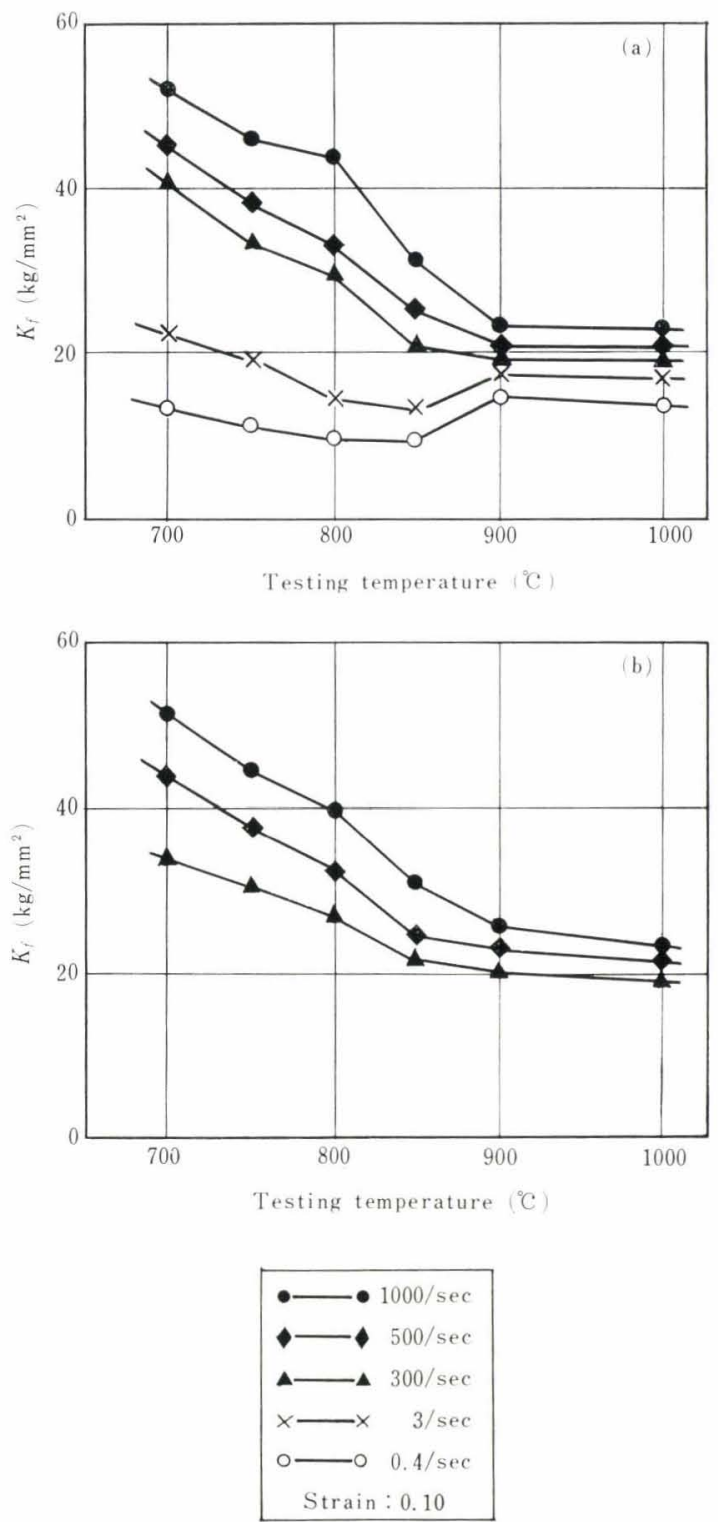

(a) $0.04 \% \mathrm{C}$ steel

(b) $0.05 \% \mathrm{C}$ steel-I

Fig. 6. Stress - temperature curves

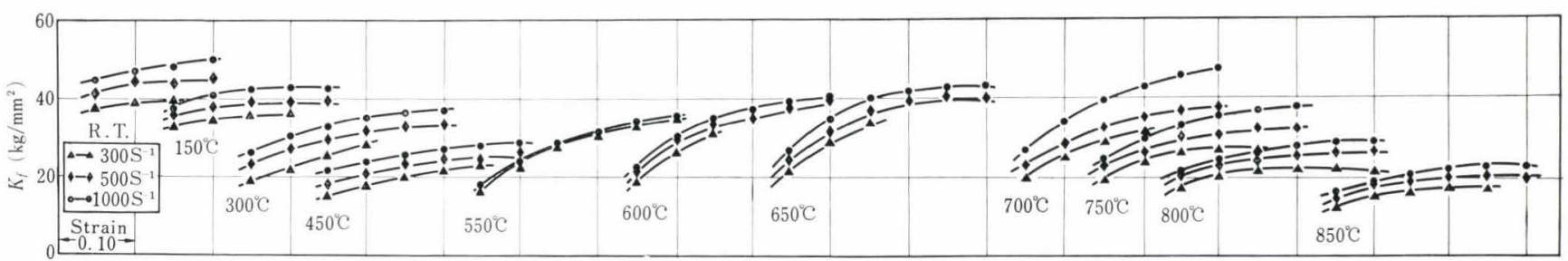

Fig. 4. $\mathrm{K}_{f}$-strain curves of $0.02 \% \mathrm{C}$ steel at various temperatures above room temperature to $850^{\circ} \mathrm{C}$

\footnotetext{
* Nippon Kokan K.K.
} 


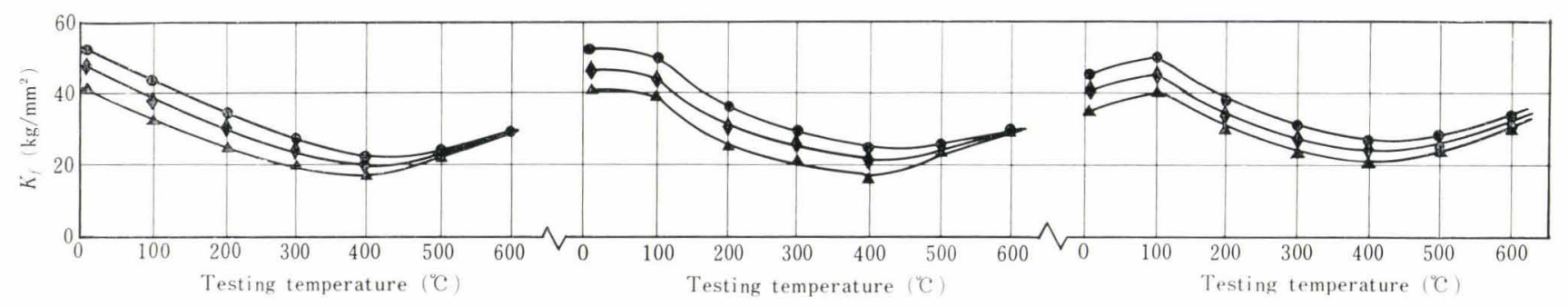

(a) $0.05 \% \mathrm{C}$-steel- II

(b) N-I steel

(c) $\mathrm{N}$ - II steel

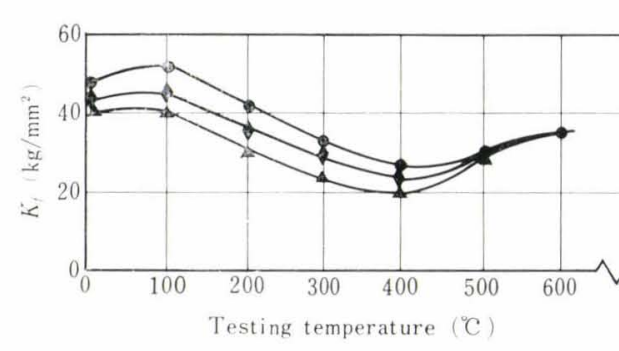

(d) $\mathrm{N}$ - III steel

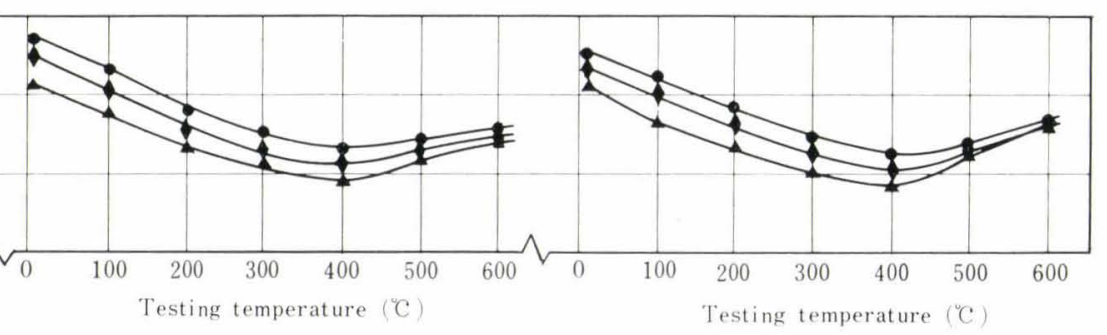

(e) C-I steel

(f) C- II steel

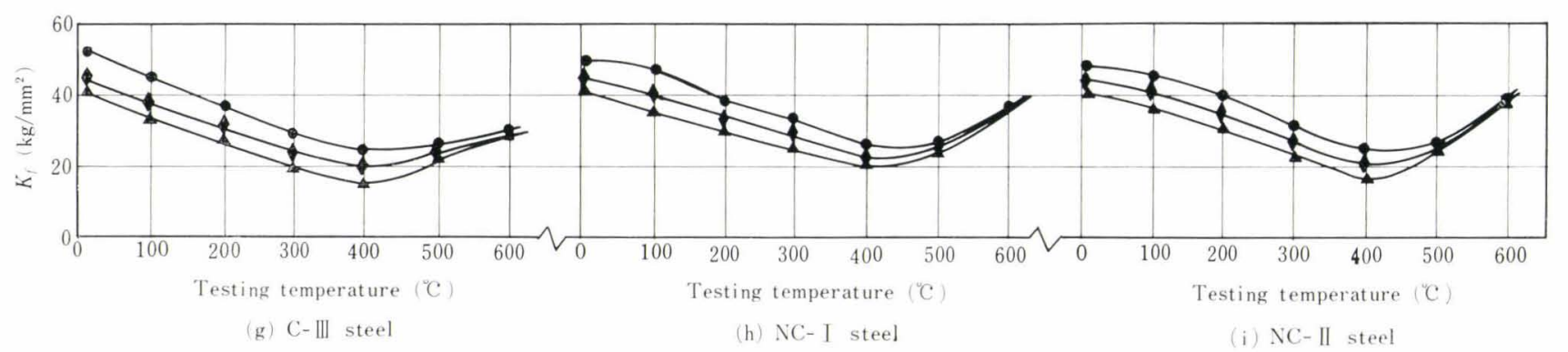

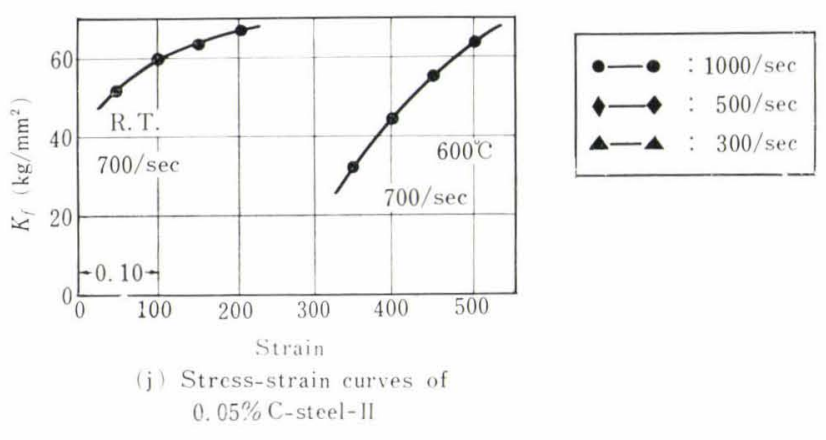

Fig. 7. (a)-(j).

Stress-temperature and strain curves of steels containing various contents of $\mathrm{Ni}$ and $\mathrm{Cr}$

Kusakabe* with the cam-plasto-meter are shown for comparison.

The peak is not present at such high strain rate, $10^{2} / \mathrm{sec}$. Especially from Fig. 6(a) the strain-rate dependence of the flow stress is clearly larger at $\alpha$-rich temperature than at $\gamma$-rich temperature. The same tendency can be said about the temperature dependence of flow stress.

$0.05 \% \mathrm{C}$ Steel-II and the Eight Sorts of $0.05 \% \mathrm{C}$ Steel Containing Small Amount of $\mathrm{Ni}$ and $\mathrm{Cr}$

For the sake of detecting the effect of substitutional alloying elements on the flow-stress behaviours such as temperature and strain-rate dependences, the specimens added $\mathrm{Ni}, \mathrm{Cr}, \mathrm{Al}$ and $\mathrm{Si}$ were prepared. This experiment about the addition of $\mathrm{Ni}$ and $\mathrm{Cr}$ has the purpose to clarify the effect of these two elements on the temperature and strain-rate dependence of the flow stress between room temperature and $600^{\circ} \mathrm{C}$.

The stress-temperature curves are shown in Fig. 7 (a)-(i). From Fig. 7, below $500^{\circ} \mathrm{C}$ the strain-rate dependence of flow stress is as large as those found in the cases of $0.09 \% \mathrm{C}$ steel and $0.02 \%$ C steel. At $100^{\circ} \mathrm{C}$, in the case of steels containing $\mathrm{Ni}$, a knick point on the stress - temperature curves is found as in the case of $0.02 \% \mathrm{C}$ steel. But for the presence of the knick point, the temperature dependence where the strain-rate dependence is large, is also large. The effect on the flow-stress behaviours mentioned above of these alloying elements is not found. In Fig. 7(j), two of the stress-strain curves of $0.05 \%$ C steel-II are shown. At $600^{\circ} \mathrm{C}$, strain-hardening occurs more rapidly than at room temperature. The strain-rate dependence between $500^{\circ}$ and $600^{\circ} \mathrm{C}$ is as small as that found in the case of $0.02 \% \mathrm{C}$ steel.

\section{$2 \%$ Al Iron}

$\mathrm{C}$ content of this alloy is less than $0.002 \%$. Then,

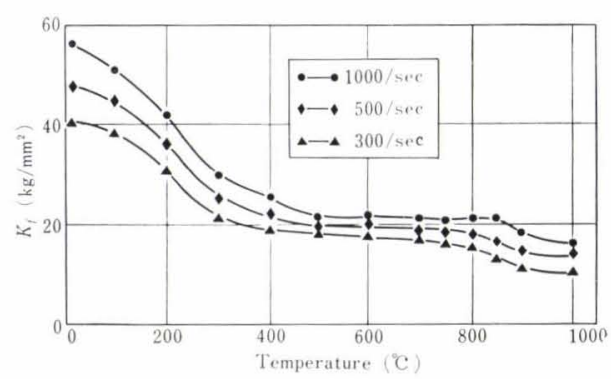

Fig. 8. Stress-temperature curves of $2 \% \mathrm{Al}$ iron (strain 0.10 ) 
with this alloy the effect of $\mathrm{C}$ and $\mathrm{Al}$ on the flow-stress behaviours can be detected. In Fig. 8 the stresstemperature curves at strain of 0.10 are shown. From Fig. 8, both of the strain-rate and temperature dependence of flow stress are large below $500^{\circ} \mathrm{C}$, become smaller between $600^{\circ}$ and $850^{\circ} \mathrm{C}$ and again larger to some extent above $850^{\circ} \mathrm{C}$. Any of peak is not found on the stress-temperature curves, but a knick is also found at $100^{\circ} \mathrm{C}$.

\section{$1 \%$ Si Iron}

The stress-temperature curves are shown in Fig. 9. The flow-stress behaviours below $300^{\circ} \mathrm{C}$ are of the same feature as the other $\mathrm{C}$ steels and alloyed irons. From $300^{\circ}$ to $650^{\circ} \mathrm{C}$, however, the strain-rate and temperature dependences of flow stress become much smaller and the level of the flow stress $20 \mathrm{~kg} / \mathrm{mm}^{2}$ higher than the flow stress of the other steels at $400^{\circ}$ $500^{\circ} \mathrm{C}$. Between $700^{\circ}$ and $850^{\circ} \mathrm{C}$ the flow stress begins to decrease drastically. Above $850^{\circ} \mathrm{C}$, the strainrate and temperature dependences of flow stress becomes much smaller.

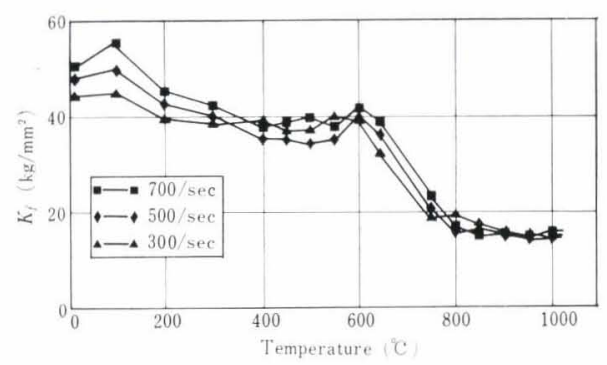

Fig. 9. Flow stress - temperature curves of $1 \% \mathrm{Si}$ iron (strain 0.10)

\section{Tantalum}

The stress-temperature curves about Ta are shown in Fig. 10. The flow stress difference between at strain rate $1000 / \mathrm{sec}$ and at $300 / \mathrm{sec}$ is also shown in the figure. Below $850^{\circ} \mathrm{C}$, the strain-rate dependence of flow stress has the same order of magnitude of the stress of iron and steel. A peak on the stress-temperature curve is detected at $500^{\circ} \mathrm{C}$ and it is due to the blue shortness of $\mathrm{Ta}$ at high strain rate $500 / \mathrm{sec}$. At strain rate, $10^{2} / \mathrm{sec}$, the blue shortness of Ta occurs in the temperature range where the strain-rate dependence of flow stress is large. This is a different point from the flow-stress behaviours of iron and steel. But for the peak below $850^{\circ} \mathrm{C}$, the temperature dependence of flow stress is of the same feature as that of iron and steel at the temperature range from room temperature to $500^{\circ} \mathrm{C}$.

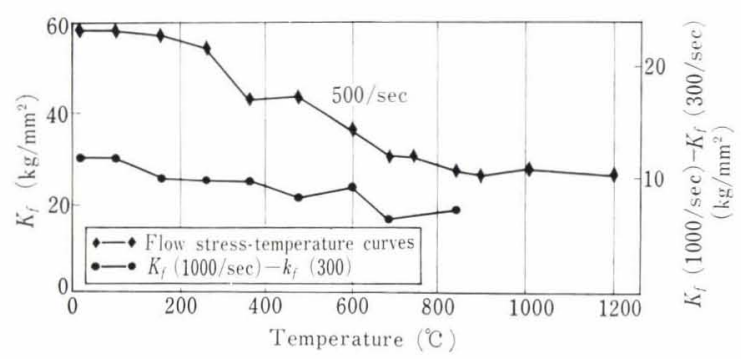

Fig. 10. Flow stress-temperature curves and strain-rate dependence of $\mathrm{Ta}$ (strain 0.10 )

\section{Discussions}

All experimental results can be summarized as shown below.

(1) From room temperature to $500^{\circ} \mathrm{C}$, the strainrate dependence of flow stress is large in the case of steel and iron alloys except for $1 \% \mathrm{Si}$ iron. Their temperature dependence is generally large in this temperature range, but in the cases of $0.02 \% \mathrm{C}$ steel, $0.05 \% \mathrm{C}$ steel containing $\mathrm{Ni}$ and $2 \% \mathrm{Al}$ iron it is small between room temperature and $100^{\circ} \mathrm{C}$.

(2) The flow stress behaviours in the case of $1 \%$ $\mathrm{Si}$ iron are of the same feature as in the cases of the other steels and iron alloys below $300^{\circ} \mathrm{C}$, but are quite different above $300^{\circ} \mathrm{C}$. The strain-rate and temperature dependences are very small at the temperature range from $300^{\circ}$ to $650^{\circ} \mathrm{C}$, and the flow-stress level is $20 \mathrm{~kg} / \mathrm{mm}^{2}$ higher than those of iron and steel at $500^{\circ} \mathrm{C}$.

(3) A peak on the stress-temperature curves of steel is found at the temperature range between $600^{\circ} \mathrm{C}$ and $700^{\circ} \mathrm{C}$. But any peak is not found in the case of $2 \% \mathrm{Al}$ iron not containing $\mathrm{C}$ nor $\mathrm{N}$ enough to occur blue shortness.

(4) In the case of steel, the strain-rate dependence of flow stress between $500^{\circ}$ and $600^{\circ} \mathrm{C}$ is small, but above $650^{\circ} \mathrm{C}$ become as large as below $500^{\circ} \mathrm{C}$.

(5) From $500^{\circ}$ to $850^{\circ} \mathrm{C}$, the strain-rate and temperature dependences of $2 \% \mathrm{Al}$ iron are small, but above $850^{\circ} \mathrm{C}$ those become a little larger.

(6) In the case of steel, the strain-rate and temperature dependences of flow stress are smaller above $A_{3}$ point. And then no peak are found on the stresstemperature curves at high strain rate, whereas a peak is found at lower strain rate at about $A_{3}$ point.

(7) In the case of Si iron the strain rate dependence of flow stress is small, but the temperature dependence is much larger between $700^{\circ}$ and $800^{\circ} \mathrm{C}$. Above $850^{\circ} \mathrm{C}$, both of those become much smaller.

(8) In the case of tantalum the behaviours of flow stress are almost similar to those in the case of steel, but a peak on the stress - temperature curve is found in the temperature range where the strain-rate dependence of flow stress is still large. Above $900^{\circ} \mathrm{C}$, temperature does not affect on the flow stress.

As for the experimental results mentioned above, some discussion will be made in the following.

First, the large temperature and strain-rate dependences from room temperature $\left(100^{\circ} \mathrm{C}\right.$ in the cases of $0.02 \% \mathrm{C}$ steel, $0.05 \% \mathrm{C}$ steel containing $\mathrm{Ni}, 2 \% \mathrm{Al}$ iron and $1 \% \mathrm{Si}$ iron) to $500^{\circ} \mathrm{C}$ (but $300^{\circ} \mathrm{C}$ in the case of $1 \% \mathrm{Si}$ iron) have the same feature as those in the case of the low temperature plasticity of iron and steel at much lower strain rate, $10^{-3}-10^{-6} / \mathrm{sec}$. For instance, if strain rate $\varepsilon$ can be related to temperature $T$ and flow stress $\tau$ effective to move dislocation by equation $(2)$ :

$$
\dot{\varepsilon}=\dot{\varepsilon}_{0} \exp \{-U(\tau) / k T\}
$$

where $\dot{\varepsilon}_{0}$ is composed of the number of moving dislocations Burger's vector, the average length of moving dislocation segments and the number of free vibrating frequencies of moving dislocations, $U(\tau)$ is the poten- 
tial barrior to moving dislocations, and a function of $\tau$ decreasing as stress increasing, and $k$ is Boltzmann's constant, $U^{\prime}(\tau)$ has the same order of magnitude as that in the case of the low temperature and low strainrate test. With eq.(2), H. Conrad, et al. analysed the low temperature and low strain-rate plasticity of iron and steel, and concluded that the controlling mechanism of the deformation is the process of double kink formation on moving dislocations because of high Peierls-Nabarro force of iron ${ }^{8)-10)}$. As for what mechanism controls the deformation, however, all other investigators did not agree to H. Conrad, et al. D.F. Stein and Low Jr., et al. studied on the plasticity of iron containing $\mathrm{C}$ and $\mathrm{N}$ lower than $5 \times 10^{-3}$ p.p.m. and found the temperature dependence of stress smaller than that of iron containing $\mathrm{C}$ and $\mathrm{N}$ higher than 1 p.p.m. Then, they concluded that the frictional stress to moving dislocations depends on the presence of $\mathrm{G}$ and N.11) On this problem, systematically experiment on $\mathrm{C}$ and $\mathrm{N}$ dependence of flow stress must be done. Such a study was done by the present authors with the low temperature creep and tensile test on iron containing various amount of $\mathrm{C}$ and $\mathrm{N}$, i.e., lower than 1 p.p.m. to 200 p.p.m. They concluded that $\mathrm{C}$ and $\mathrm{N}$ affect the pre-exponential factor of right side of eq. (2), i.e., moving dislocation density and then $\tau$ increases because of need of decreasing $U(\tau)^{12)}$.

In this paper, the strain-rate and temperature dependences of flow stress of Ta are measured for the sake of comparing with those in the case of iron and steel. In the case of Ta, a peak on the stress - temperature curve due to the interstitial impurities is found in the temperature range where the strain-rate dependence of flow stress is large. The temperature dependence of flow stress above $450^{\circ} \mathrm{C}$, at which the flow-stress peak exists, is large up to the temperature, $850^{\circ} \mathrm{C}$ and becomes very small above $900^{\circ} \mathrm{C}$. If the strain-rate dependence is caused by the same deformation mechanism both below and above $450^{\circ} \mathrm{C}$ and the strain-rate dependence is also small above $900^{\circ} \mathrm{C}$, it is possible to compare the case of iron with that of Ta.

The strain-rate and temperature dependences of flow stress of iron and steel (especially $2 \% \mathrm{Al}$ iron) are small above $500^{\circ} \mathrm{C}\left(\fallingdotseq 800^{\circ} K\right)$ and those of Ta are also small above $900^{\circ} \mathrm{C}\left(\fallingdotseq 1200^{\circ} K\right)$. Above those temperature, the flow-stress component due to the fricitional stress determined by the controlling deformation mechanism is zero. Then from eq.(2), the ratio of $U(0)$ in the case of Ta to that in the case of iron is obtained, assuming that $\dot{\varepsilon}_{0}$ of eq. (2) does not differ above 10 fold from each other in the both of two cases. Then,

$\exp \{-U(0) \mathrm{Fe} / k \cdot 800\}=\exp \{-U(0) \mathrm{Ta} / k \cdot 1200\} \ldots(3)$

where $U(0) \mathrm{Fe}$ is $U(0)$ in the case of iron and $U(0)$ $\mathrm{Ta}$ in the case of Ta. From eq. (3), $U(0) \mathrm{Ta} / U(0) \mathrm{Fe}$ $=1.5$ is obtained. If the controlling mechanism is that of double kink formation process as proposed by $\mathrm{H}$. Conrad, et al., $U(0)$ must be proportional to $\mu b^{3}$ where $\mu$ is the shear modulus. $\mu b^{3}$ of iron is 11 ergs, that of Ta is $16 \mathrm{ergs}$, and then the ratio is also 1.5. This is favourable result for concluding the deformation mech- anism to be that of the double kink formation process. In the case of iron, $U^{\prime}(\tau)$ obtained by $\Delta \ln \dot{\varepsilon} \mid \Delta K_{f}$ from the experimental data varies from $<10 b^{3}$ to $30 b^{3}$, respectively from room temperature to $500^{\circ} \mathrm{C}$, and almost the same result is obtained in the case of Ta. Such a magnitude of $U^{\prime}(\tau)$ is also favourable to conclude the double kink formation mechanism to control the deformation. But now one problem exists. It is whether the strain-rate history of deformation affects the structure of materials at 0.10 strain. But in other papers the present authors treated this problem, and conclude that neither strain rate nor temperature affect on the structure where flow stress seems to be determined by the double kink formation mechanism. ${ }^{12), 16)}$

The flow-stress behaviours of $\mathrm{Si}$ iron above $300^{\circ} \mathrm{C}$ is quite different from those of iron and steel. From $300^{\circ}$ to $650^{\circ} \mathrm{C}$ the flow stiess of $1 \% \mathrm{Si}$ iron does not depend on temperature and strain rate, and is about $20 \mathrm{~kg} / \mathrm{mm}^{2}$ higher than that at $500^{\circ} \mathrm{C}$ of iron and steel. This high stress level must be interpreted by the presence of Si atoms. About 10 years ago, Fisher proposed a hardening mechanism by $\mathrm{Si}$ atom in iron by which he interpreted the preferential activity of $\{110\}\langle 111\rangle$ slip system in high Si iron. ${ }^{13}$ The hardening mechanism is called "local or short range order" hardening. Now there is no knowledge about the binding energy of Si-Fe pair enough to calculate the stress to hinder the moving dislocations. It is possible to understand that the strain-rate and temperature dependences are small if the local ordering hinders the dislocation motion, because the effective hindering path of this mechanism can be expected long enough to avoid the effect of thermal fluctuation of dislocations to the contrast to the double kink formation mechanism or jog dragging mechanism. The large temperature dependence above $700^{\circ} \mathrm{C}$ may correspond to the rapid decrease of the stress by destroying of the local order, if it is true that the flow stress is determined by "local ordering " mechanism between $300^{\circ}$ and $650^{\circ} \mathrm{C}$.

Now, the peak on the stress-temperature curves is discussed below. The peak is due to the interstitial impurities. The reason why flow stress increases from $500^{\circ}$ to $650^{\circ} \mathrm{C}$, however, is not yet clear. The mechanisms proposed now are agreeable on a point that the diffusivity of interstitials relates to dislocation velosity. But some investigators proposed the mechanism as that of dragging interstitials of dislocation. ${ }^{14)}$ At lower temperature the diffusivity of interstitials is too low to move with dislocations and at higher temperature that is high enough to be free from dislocations. Then at optimum temperature this dragging effect on the flow stress is the highest. But the dragging mechanism mentioned above is unable to explain the high work-hardening rate at the peak temperature as shown in Figs. 1, 2 and $7(\mathrm{j})$. This high work-hardening rate is due to the rapid multiplication of dislocations as shown by transmission electron microscopy ${ }^{15)}$. Then the high stress level at the peak temperature is interpreted not by the dragging stress but by the back stress due to the 
high dislocation density. The reason why the dislocation density varies with temperature and is affected by interstitials, is not yet clear.

The discussion mentioned above about the flowstress peak is also able to be adopted to explain the large temperature and strain-rate dependences above the peak temperature. The cause of the dependences must be interpreted in the same way by the interaction between dislocations and interstitial impurities.

Then in the temperature range of coexisting of $\alpha$ - and $\gamma$-phase, no peak on the stress-temperature curves are found at higher strain rate, whereas at lower strain rate a peak exists there. The strain-rate dependence of flow stress of $\alpha$-phase is larger than that of $\gamma$-phase as shown in Fig. 6(a). This is the reason why a peak exists at lower strain rate and disappears at higher strain rate.

In the case of $2 \% \mathrm{Al}$ iron, neither a peak due to the interstitial impurities nor a peak due to $\alpha-\gamma$ transformation exists. However, above $850^{\circ} \mathrm{C}$ the strain-rate and temperature dependences are a little larger. This seems due to the self diffusion enough to affect the structural change during deformation.

\section{Conclusions}

(1) Many investigators report that the strain-rate dependence of flow stress of metals and alloys increases with temperature. But in the authors' experiment, such a general conclusion can not be adopted to those in the cases of iron, steel and Ta at strain rate of $10^{2} / \mathrm{sec}$.

(2) At lower temperature, the large strain-rate dependence of flow stress is found in the case of steel, $2 \% \mathrm{Al}$ iron and $\mathrm{Ta}$. The temperature dependence corresponds almost always to the strain-rate dependence, but that of $0.02 \% \mathrm{C}$ steel, $0.05 \% \mathrm{C}$ steel containing $\mathrm{Ni}$, and $\mathrm{Ta}$ is small at the lowest part (below $100^{\circ} \mathrm{C}-$ $150^{\circ} \mathrm{C}$ for steel and $200^{\circ} \mathrm{C}$ for $\mathrm{Ta}$ ) of the temperature range.

(3) In the case of Ta, a peak of the stress - temperature curve is found where the strain-rate dependence of flow stress is large. It is the different point of flowstress behaviour from those in the case of iron or steel.

(4) The flow stress behaviours at lower temperature mentioned above can be interpreted by the double kink formation mechanism on moving dislocations,

(5) In the case of Si iron, the flow-stress behaviours below $300^{\circ} \mathrm{C}$ is of the same nature as those of iron or steel. But those above $300^{\circ} \mathrm{C}$ must be due to the local ordering effect.
(6) A peak found on the stress - temperature curves of steel at $600^{\circ}-650^{\circ} \mathrm{C}$ must be due to the interaction between dislocations and interstitials. But the dragging mechanism fails to explain the high work-hardening rate and high density of dislocations. So the other mechanism is necessary to explain, but it is not yet clear.

(7) In the $\alpha$ - $\gamma$-coexisting temperature range, at higher strain rate no peak is found on the stress-temperature curves, whereas at lower strain rate a peak exists. The reason is that the strain-rate dependence of flow stress is higher in $\alpha$-phase temperature than in $\gamma$-phase temperature.

(8) In the case of $2 \% \mathrm{Al}$ iron, both the strain-rate and temperature dependences of flow stress are small from $500^{\circ}$ to $850^{\circ} \mathrm{C}$, and then become larger above $900^{\circ} \mathrm{C}$. It seems that above $850^{\circ}-900^{\circ} \mathrm{C}$ the self diffusion is active enough to cause the recovery during deformation.

\section{Acknowledgement}

The authors wish to express their sincere appreciation to Dr. K. Gunji, National Research Institute for Metals, and Mr. T. Nara, Research Institute for Electrical Communication of Japan Telephone and Telegraph Bureau, for the sample preparations.

Sincere appreciations are also due to $\mathrm{Mr}$. T. Ninomiya and $\mathrm{Mr}$. H. Kondo for their assistance.

\section{REFERENCES}

1) A. Nadai \& M. Manjoine: Proc. Amer. Soc. Testing Materials, (1940), 822.

2) S. Sakui, M. Nakamura, et al. : Tetsu-to-Hagané, 48 (1962), $28 ; 48$ (1962), 1441; 49 (1963), 996.

3) J. Matsuura: Kikai-Gakkai-shi, 62 (1959), 1387.

4) S. Hashizume: Dr. thesis, 1961/3.

5) J. Alder: J. Inst. Met., 83 (1954 \& '55), 83.

6) K. Inoue: Tetsu-to-Hagané, 41 (1955), 5, 6, 8.

7) H. Henneck: Stahl u. Eisen, 48 (1928), 315.

8) H. Conrad: J. Iron \& Steel Inst. (U.K.), 364 (1961), 198.

9) H. Conrad \& S. Frederik: Act. Met., 10 (1962), 1013.

10) H. Conrad: "The Relation between the Structure and Mechanical Properties of Metals ", (1963), 476 [London: Her Majesty's Stationery Office].

11) D. F. Stein \& J. R. Low Jr., et al. : Act. Met., 11 (1963), 1253.

12) I. Gokyu \& J. Kihara: to be published.

13) J. C. Fisher: Act. Met., 2 (1954), 9.

14) P. A. Flinn: "Strengthening Mechanisms in Solid", (1962), 38, [A.S.M.].

15) I. Gokyu \& K. Hashimoto: to be published.

16) I. Gokyu \& J. Kihara: J. Japan Inst. Metals, 29 (1965), 271. 